\title{
APLIKASI PENGUKUR TINGKAT PH DAN ZAT PADAT TERLARUT PADA IN- STALASI PENGOLAHAN AIR LIMBAH UNTUK TANAMAN HIDROPONIK MENGGUNAKAN SENSOR PH METER DAN TDS METER
}

\author{
Dwi Rahma Ida Susanti1, Ayu Kartika Puspa2 \\ 1Fakultas Ilmu Komputer, Universitas Bandar Lampung \\ J1. Zainal Abidin Pagar Alam No.26, Labuhan Ratu, Kedaton, 35142, Bandar Lampung, Indonesia E-mail: \\ ayukartikapuspa@ubl.ac.id \\ dwi.17411037@student.ubl.ac.id
}

\begin{abstract}
ABSTRAK
Instalasi Pengolahan Air Limbah adalah Saluran Pembuangan Limbah Bersama/Komunal. Saluran ini mengalirkan limbah rumah tangga dari tiap rumah ke instalasi pengolahan limbah masyarakat setempat, atau ke sistem pembuangan limbah kota. Namun pada umumnya hasil akhir air limbah IPAL (Instalasi Pengolahan Air Limbah) hanya dialirkan kesungai dan tidak dimanfaatkan kembali untuk hal yang terarah. Air hasil akhir yang dikeluarkan oleh IPAL (Instalasi Penolahan Air Limbah) telah melalu beberapa proses diantaranya, Grit Chamber (penangkap padatan), Equalisasi, Settler, Anaerobic Buffle Reactor, Anaerobic Filter. Dari proses pengolahan air limbah tersebut air yang dihasilkan merupakan air jernih, namun untuk tingkah ph dan zat padat terlarut belum diketahui. Maka diperlukan sebuah alat dan aplikasi yang dapat mengukur kadar air pada air limbah. Berdasarkan alasan tersebut penelitian ini dilakukan untuk mengukur tingkat $\mathrm{PH}$ dan zat padat terlarut menggunakan sensor $P H$ meter dan TDS meter dan microcontroller menggunakan nodeMCU ESP8266 dan memberikan rekomendasi tanaman hidroponik berdasarkan nilai dari sensor PH meter.
\end{abstract}

Kata kunci: Instalasi Pengolahan Air Limbah; sensor PH meter; sensor TDS meter; nodeMCU ESP8266; hidroponik.

\begin{abstract}
Wastewater Treatment Plants are Collective / Communal Sewerage Channels. These drains carry household waste from each household to a local community sewage treatment plant, or to a municipal sewage system. However, in general, the end product of the IPAL (Wastewater Treatment Plant) wastewater is only channeled into the river and is not reused for directed purposes. The final water released by the IPAL (Wastewater Treatment Plant) has gone through several processes including, Grit Chamber (solids catcher), Equalization, Settler, Anaerobic Buffle Reactor, Anaerobic Filter. From the wastewater treatment process, the water produced is clear water, but the $\mathrm{pH}$ and dissolved solids are unknown. So we need a tool and application that can measure the water content in wastewater. Based on these reasons, this research was conducted to measure the level of $\mathrm{PH}$ and dissolved solids using a PH meter and TDS meter sensor and a microcontroller using the nodeMCU ESP8266 and provide recommendations for hydroponic plants based on the value of the $\mathrm{PH}$ meter sensor.
\end{abstract}

Keyword: Wastewater Treatment Plant; PH meter sensor; sensor TDS meter; NodeMCU ESP8266; hidroponik. 


\section{Pendahuluan}

Demi mewujudkan suatu daerah yang lebih berkembang dan modern, Desa way galih membuat program kerja salah satu program pertanian hidroponik dengan memanfaatkan air dari instalasi pengolahan air limbah (IPAL). Sistem pertanian hidroponik juga bisa menjadi salah satu solusi untuk tetap bercocok tanaman dilahan yang terbatas, keunggulan lainnya adalah kandungan vitaminnya lebih baik dibandingkan dengan tanam sistem langsung dan tentunya mempunyai nilai ekonomis yang tinggi. Namun tidak semua jenis air dapat digunakan untuk budidaya tanaman hidroponik. Air yang cocok untuk media hidroponik yaitu, air hujan, air sumur biasa, air tetesan pendingin ruangan (AC) hingga air isi ulang atau reverse osmosis. Dengan kondisi ketersediaan air bersih diberbagai daerah diIndonesia hingga saat ini memprihatinkan, dengan ini penulis mencoba memanfaatkan kembali air limbah domestic dari instalasi pengolahan air limbah (IPAL) sebagai media untuk menyirami tanaman hidroponik. Tujuan dibangunnya instalasi pengolahan air limbah (IPAL) yaitu untuk menimalisir terjadinya penyerapan air limbah rumah tangga secara langsung kedasar permukaan tanah serta genangan air disekitar rumah penduduk dari limbah rumah tangga yang langsung mengalir bebas ketanah tanpa ada penyaluran perpipaan sehingga dapat mencemari lingkungan. Instalasi pengolahan air limbah (IPAL) digunakan untuk penampungan limbah domestik yang terdiri dari limbah rumah tangga dan septic tank dimana hasil dari pengolahan limbah tersebut berupa air. Dari kondisi yang telah penulis paparkan dengan ini penulis membuat suatu aplikasi yang dapat mengukur tingkat PH menggunakan sensor PH meter dan zat padat terlarut menggunakan sensor TDS meter pada air limbah domestic IPAL (instalasi pengolahan air limbah) untuk tanaman hidroponik. Aplikasi ini dapat memberikan informasi dan solusi mengenai pemanfaatkan kembali air limbah domestic pada IPAL (instalasi pengolahan air limbah) untuk tanaman hidroponik. Yang mana penelitian ini berjudul “Aplikasi Pengukur Tingkat Ph Dan Zat Padat Terlarut Pada Instalasi Pengolahan Air Limbah Untuk Tanaman Hidroponik Menggunakan Sensor Ph Meter Dan Tds Meter"

\section{Tinjauan Pustaka}

\subsection{IPAL (Instalasi Pengolahan Air Limbah)}

IPAL atau Instalasi pengolahan air limbah merupakan sarana pengolahan limbah cair yang berupa limbah rumah tangga yaitu air cuci piring, air kamar mandi, air cuci baju dan juga septic tank. Tujuan dibangunnya IPAL yaitu untuk meminimalisir genangan disekitar lingkungan serta penyerapan septic tank secara langsung kedasar permukaan tanah yang dapat mengakibatkan tercemar dan berkurangnya nutrisi tanah baik untuk air bersih maupun tumbuhan.

\subsubsection{Sensor PH meter}

Sensor $\mathrm{pH}$ dibuat dengan kontruksi untuk menangkap aktifitas ion hydrogen ( menggunakan elektroda gelas kaca (glass electrode) yang ujungnya terbuat dari kaca tipis dan bulat (bulb) yang terisi larutan $\mathrm{HCl}(0,1 \mathrm{~mol} / \mathrm{dm} 3)$. Pada larutan tersebut dicelupkan kawat perak sehingga terbentuk persenyawaan yang seimbang dengan larutan $\mathrm{HCl}$ membentuk $\mathrm{AgCl}$. Pada keadaan ini larutan pada bulb memungkinkan bertukar ion $\mathrm{H}+$. Sensor $\mathrm{pH}$ secara konsep memiliki keluaran analog. Arus yang mengalir pada sensor akibat ionisasi secara otomatis berubah menjadi tegangan melalui impedansi rangkaian pengkondisian sinyal. Arus hasil pertukaran ion berubah menjadi tegangan akibat dihubungkan Opamp yang memiliki impedansi input tinggi. Keluaran penguat adalah tegangan analog pada pin P_Aout. Masalah yang penting pada sistem akusisi data ini adalah belum diinformasikannya karakteristik sensor yang menunjukkan hubungan antara nilai pH yang 81 Teknologi Sensor diukur ter- 
hadap tegangan keluaran pada pin $\mathrm{P}_{-}$Aout. Oleh karena itu perlu dilakukan karakterisasi dengan $\mathrm{pH}$-meter standard untuk memperoleh hubungan antara $\mathrm{pH}$ terukur dengan tegangan keluaran pengkondisian sinyal sensor. Hasil tersebut selanjutnya dimasukkan dalam script program untuk mengubah nilai ADC menjadi nilai $\mathrm{pH}$ kembali di computer (Dr. Suryono, 2018)

\subsection{Sensor TDS meter}

Sensor $\mathrm{pH}$ secara konsep memiliki keluaran analog. Arus yang mengalir pada sensor akibat ionisasi secara otomatis berubah menjadi tegangan melalui impedansi rangkaian pengkondisian sinyal. Arus hasil pertukaran ion berubah menjadi tegangan akibat dihubungkan Op-amp yang memiliki impedansi input tinggi. Keluaran penguat adalah tegangan analog pada pin P_Aout.

\subsection{Hidroponik}

Sejak abad ke-16, percobaan tentang ilmu nutrisi dengan mengembangkan metode pertanian hidroponik telah dimulai. Semenjak itu, metode pertanian dengan hightechnology ini menjadi lebih populer dan dikenal di seluruh dunia. Hidroponik berasal dari bahasa Latin hydros yang berarti air dan phonos yang berarti kerja. Arti harfiah dari hidroponik adalah kerja air. Bertanam secara hidroponik kemudian dikenal dengan bertanam tanpa medium tanah (soilless cultivation, soilless culture). Mulanya, orang bertanam dengan metode hidroponik menggunakan wadah yang berisi air yang telah dicampur dengan pupuk mikro maupun makro (Masduki, 2017)

\section{Metodologi}

\subsection{Metode Eksperimen}

Metode eksperimen adalah metode penelitian untuk menguji apakah variable variable eksperimen efektif atau tidak. Untuk menguji efektif tidaknya harus digunakan variable control. Penelitian eksperimen adalah untuk menguji hipotesis yang dirumuskan secara ketat. Penelitian eksperimen biasanya dilakukan untuk bidang yang bersifat eksak. Sedangkan untuk bidang social biasanya digunakan metode survey eksplanatory, metode deskriptif, dan historis. (Prof.Dr Suryana, 2010)

\subsection{Metode Pengumpulan Data}

\subsubsection{Observasi}

Pada tahap ini penulis secara langsung melakukan observasi dan memahami cara kerja dari Sensor PH dan TDS meter serta Nodemcu. Cara kerja dari masing masing alat dapat diuraikan sebagai berikut:

1. Sensor PH meter dapat membaca kadar air sesuai jenis air yang dideteksi

2. Sensor TDS meter dapat membaca kadar air sesuai jenis air yang dideteksi

3. NodeMCU hanya memiliki satu slot pin analog, pada alat yang peneliti buat membutuhkan dua slot pin analog untuk masing masing sensor sehingga alternatifnya menggunakan dua nodeMCU

\subsubsection{Studi Dokumen}

Pada tahap ini penulis mengacu pada beberapa jurnal dari penelitian sebelumnya yang berhubungan dengan penelitian ini sebagai bahan dan referensi dalam penelitian yang sedang dilakukan.

\subsubsection{Wawancara}

Pada tahap ini penulis melakukan kegaiatan wawancara kepada Dika Trianda Sebagai Tenaga Fasilitator Lapangan. Hal ini dilakukan untuk mendapatkan informasi serta data dalam penelitian yang sedang dilakukan.

\subsubsection{Kebutuhan perangkat keras (Hardware)}

Pada penelitian ini perangkat keras atau hardware yang digunakan untuk menyelesaikan penelitian ini antara lain :

1. 1 buah Sensor $\mathrm{PH}$, digunakan untuk mengukur derajat asam atau basa pada air Limbah IPAL sebagai objek untuk dideteksi 

digunakan untuk mengukur niali ppm atau zat padat terlarut pada air Limbah IPAL sebagai objek untuk dideteksi

3.

2 buah microcontrolle Nodemcu, digunakan sebagai modul perantara untuk mempercepat proses pengirimian data dari sensor ke aplikasi android

4. Kabel jumper, digunakan sebagai penghubung antar komponen dari sensor ke nodemcu

\subsubsection{Kebutuhan perangkat lunak (Software)}

Pada penelitian ini perangkat lunak atau software yang digunakan untuk menyelesaikan penelitian ini antara lain :

1. Arduino IDE, digunakan untuk menulis menconvert code dalam microcontroller

2. Android studio, adalah design interface hingga aplikasi tersbut dapat digunakan oleh pengguna atau biasa disebut sebagai front end

3. Node JS merupakan platform untuk menjalankan kode JavaScript pada sisi server. Ia bertugas untuk mengeksekusi kode JavaScript sebelum halaman applikasi atau website ditampilkan dibrowser atau biasa disebut bagian back end.

4. Fritzing, digunakan untuk menggambar desain alat

5. Postman, digunakan untuk uji coba Rest API

6. Mongodb, digunakan untuk menyimpan database

7. Microsoft word 2016, digunakan untuk mngolah data dalam penulisan penelitian

8. Microsoft visio, digunakan untuk membuat alur flowchart system

\subsubsection{Flowchart system}

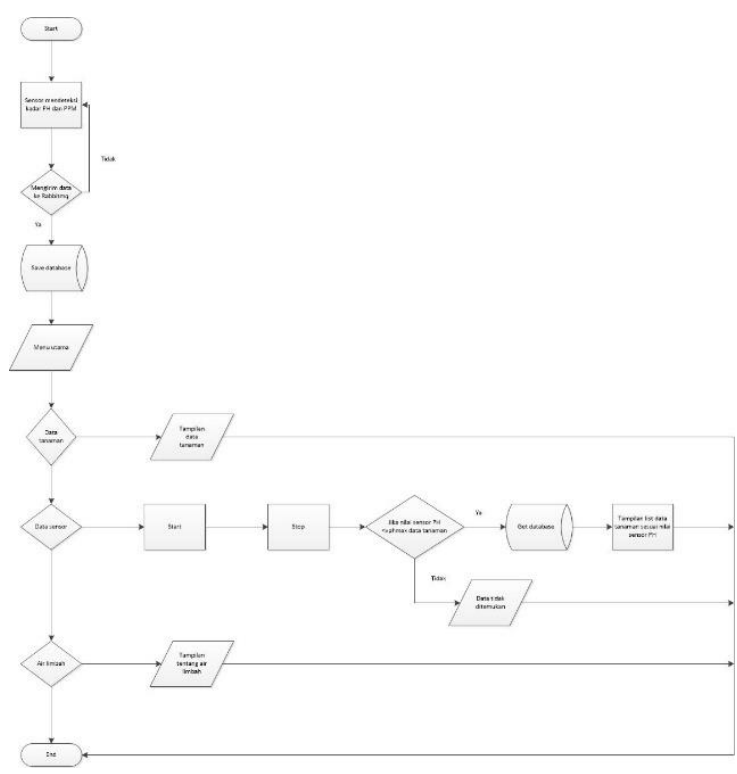

Gambar 1. flowchart sistem

Berikut adalah penjelasan dari flowchart sistem:

1. Sensor PH meter dan TDS meter mendeteksi kadar $\mathrm{PH}$ dan zat padat terlarut pada air, jika berhasil mendapatkan nilai dari kedua sensor tersebut maka data dari kedua sensor akan dikirim secara online kerabbitmq dan disimpan kedatabase, namun jika sensor tidak berhasil mendapatkan nilai maka sensor akan mencoba mendeteksi ulang.

2. Kemudian untuk menu data tanaman, saat user melakukan klik pada menu data tanaman maka akan muncul halaman yang berisi tabel data tanaman hidroponik

3.

enu data sensor, tersedia informasi berupa PH dan PPM dan terdapat tombol start dan stop, jika user melakukan klik pada tombol start maka akan menampilkan informasi $\mathrm{PH}$ dan PPM secara realtime. Kemudian jika user melakukan klik pada tombol stop dan data $\mathrm{PH}$ realtime sesuai dengan data tanaman 
hidroponik pada database maka akan menampilkan rekomedasi tanaman hidroponik, tetapi jika data $\mathrm{PH}$ realtime tidak sesuai dengan data tanaman hidroponik pada database maka akan tampil keterangan bahwa data tanaman 4. tidak ditemukan.

enu air limbah, jika user menklik menu air limbah maka akan tampil halaman penjelasan tentang air limbah IPAL

\subsubsection{Usecase Diagram System}

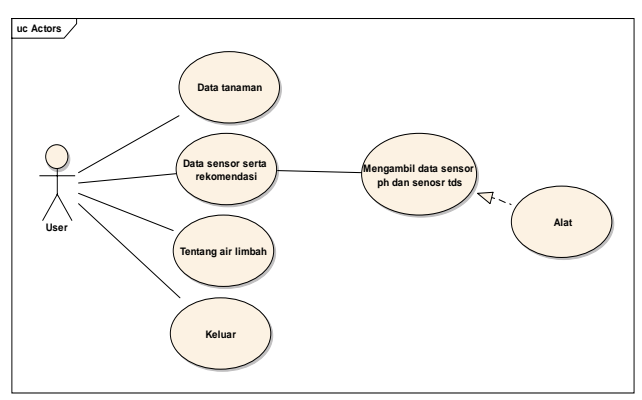

Gambar 2 Usecase diagram sistem

\section{Hasil dan Pembahasam}

\subsection{Instalasi Alat}

\subsubsection{Rangkaian Sensor PH meter dan NodeMCU ESP8266}

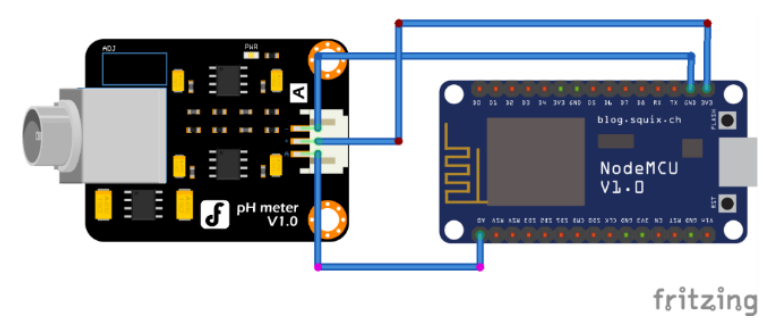

Gambar 3. Rangkaian sensor ph meter dan nodemcu esp8266

\subsubsection{Hasil Sensor PH meter Pada Serial Monitor Arduino IDE}

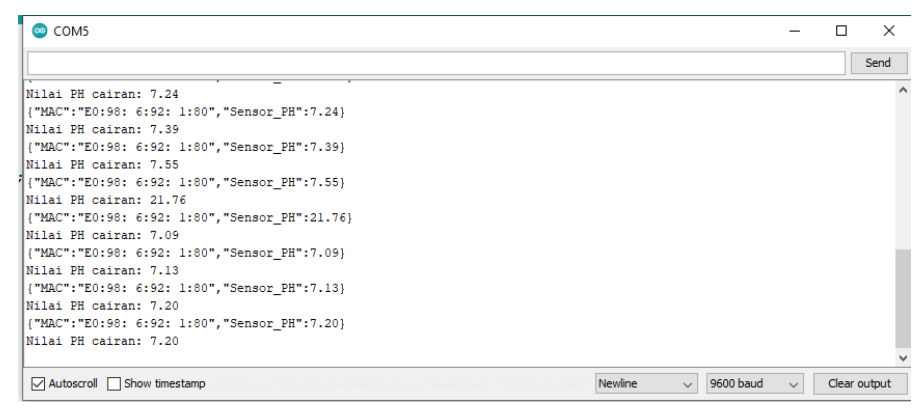

Gambar 4. Hasil sensor ph meter pada serial monitor arduino IDE

\subsubsection{Rangkaian Sensor TDS meter dan NodeMCU ESP8266}

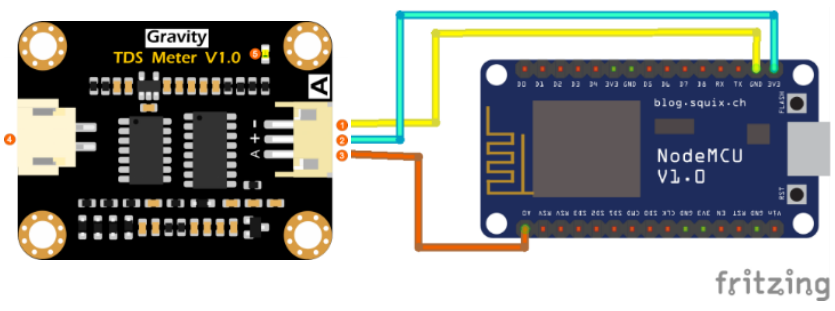

Gambar 5. Rangkaian sensor tds meter dan nodemcu esp8266

\subsubsection{Hasil Sensor TDS meter Pada Serial Monitor Arduino IDE}

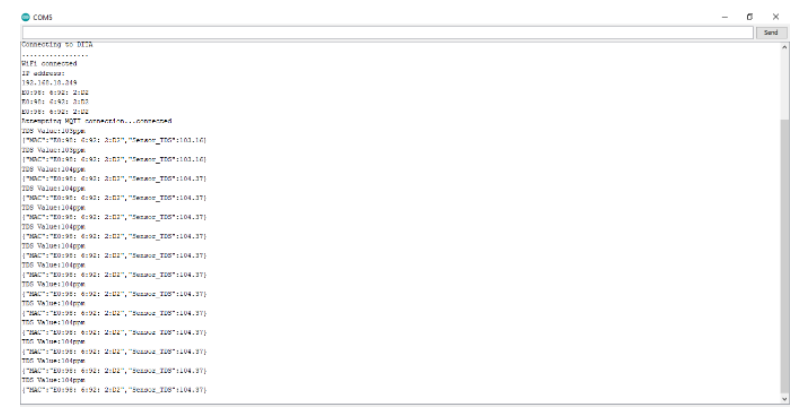

Gambar 6. Hasil sensor tds meter pada serial monitor arduino IDE

\subsubsection{Aplikasi}

Pada menu dashboard terdapat beberapa tombol yang juga termasuk sebagai menu. Menu tersebut diantaranya yaitu menu data tanaman, data sensor, dan air limbah. Berikut adalah penjelasan dari tiap tiap menu yaitu :

1. Menu data tanaman : saat user mengklik menu data tanaman maka system akan menampilkan data tanaman.

2. Menu data sensor : saat user mengklik menu data sensor maka akan tampil tampilan yang berisi data PH dan PPM. Jika user mengklik tombol start yang terdapat pada tampilan data sensor maka secara otomatis akan tampil data PH dan PPM realtime saat alat dijalankan. Kemudian jika 
user mengklik tombol stop akan menampilkan rekomendasi jenis tanaman hidroponik berdasarkan data $\mathrm{PH}$ dari alat.Menu air limbah : saat user mengklik menu air limbah maka akan tampil tampilan berupa penjelasan mengenai air limbah pada IPAL (Instalasi Pengolahan Air Limbah).

3. Menu air limbah : saat user mengklik menu air limbah maka akan tampil tampilan berupa penjelasan mengenai air limbah pada IPAL (Instalasi Pengolahan Air Limbah).

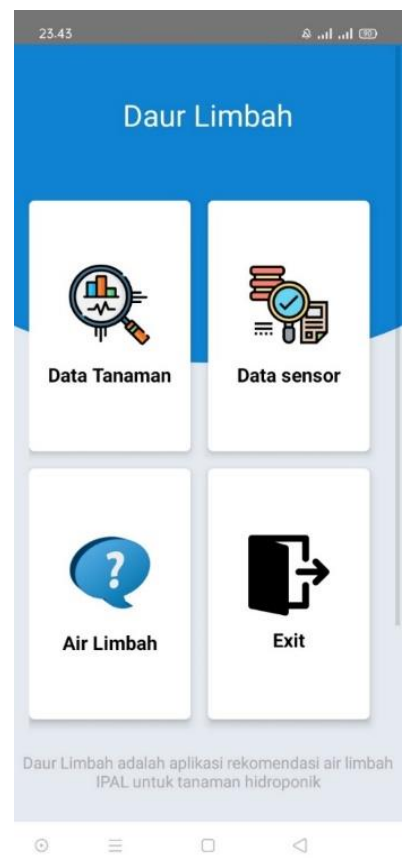

Gambar 7. Interface menu dashboard

Pada menu data tanaman tampilan yang disediakan yaitu berupa tampilan tabel data tanaman hidroponik yang mana isi dari tabel tersebut berupa jenis, ph, dan ppm. Untuk lebih jelasnya, berikut tampilan dari menu data tanaman.

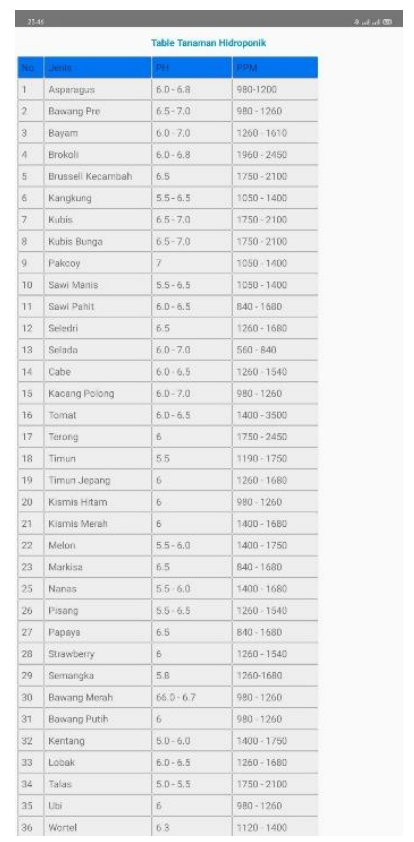

Gambar 8. Interface menu data tanaman

Menu data sensor yaitu berisi tampilan data PH dan PPM yang didapat dari sensor PH meter dan sensor TDS meter, pada saat button start diklik maka hasil dari masing masing sensor akan tampil pada halaman data sensor yang telah dikirim ke rabbit mq secara online, kemudian jika user mengklik button stop maka akan secara otomatis memberikan rekomendasi berupa jenis tanaman hidroponik berdasarkan nilai dari $\mathrm{PH}$, jika data dari sensor $\mathrm{PH}$ sesuai dengan data tanaman hidroponik. Dan apabila data tidak sesuai maka akan menampilkan "data tanaman tidak ditemukan. Berikut adalah hasil dari pengujian air limbah dalam aplikasi. 


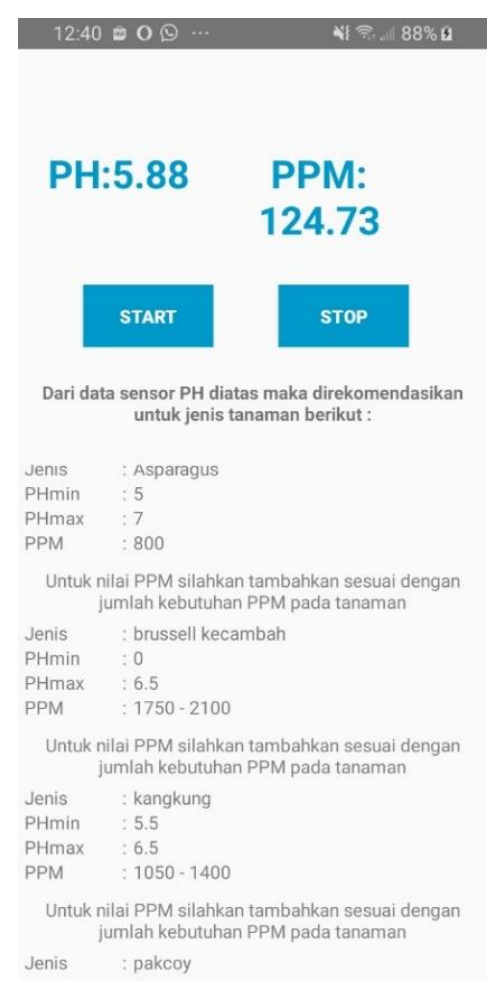

Gambar 9. Interface menu data sensor

Pada menu air limbah yaitu berisi tampilan tentang penjelasan mengenai air limbah IPAL dan juga informasi contact person dari developer.
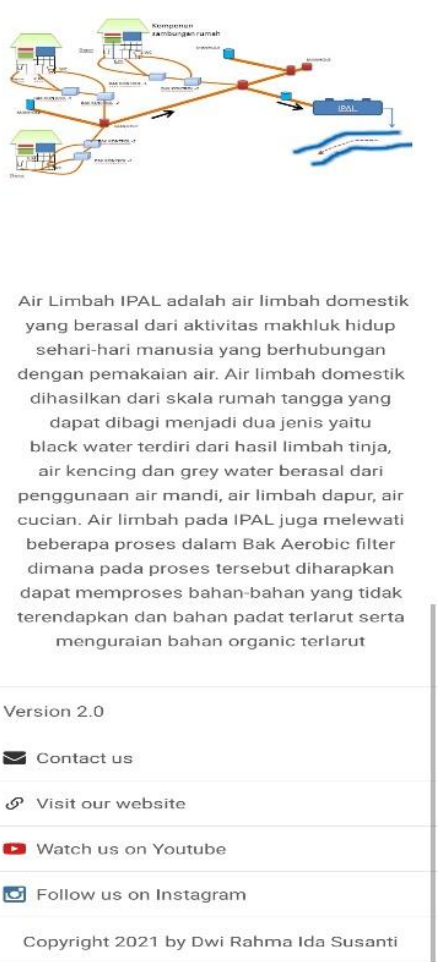

Gambar 10. Interface menu air limbah

\subsection{Pengujian Aplikasi \\ 4.2.1 Blackbox testing}

Tabel 1. Blackbox testing

\begin{tabular}{|l|l|l|l|l|l|}
\hline No. & $\begin{array}{l}\text { Seknario } \\
\text { pen- } \\
\text { gujian }\end{array}$ & Aksi & $\begin{array}{l}\text { Kasus } \\
\text { pen- } \\
\text { gujian }\end{array}$ & $\begin{array}{l}\text { Hasil yang } \\
\text { diharap- } \\
\text { kan }\end{array}$ & $\begin{array}{l}\text { Hasil } \\
\text { pen- } \\
\text { gujian }\end{array}$ \\
\hline 1. & $\begin{array}{l}\text { Icon } \\
\text { Aplikasi }\end{array}$ & Klik & $\begin{array}{l}\text { User } \\
\text { masuk } \\
\text { kemenu } \\
\text { utama }\end{array}$ & $\begin{array}{l}\text { User } \\
\text { masuk } \\
\text { ke- } \\
\text { menu } \\
\text { utama }\end{array}$ & Sesuai \\
\hline 2. & $\begin{array}{l}\text { Tombol } \\
\text { data } \\
\text { tanaman }\end{array}$ & Klik & $\begin{array}{l}\text { User } \\
\text { masuk } \\
\text { ketampi- } \\
\text { lan data }\end{array}$ & $\begin{array}{l}\text { User ma- } \\
\text { suk ket- } \\
\text { ampilan } \\
\text { data tana- }\end{array}$ & Sesuai \\
\hline
\end{tabular}




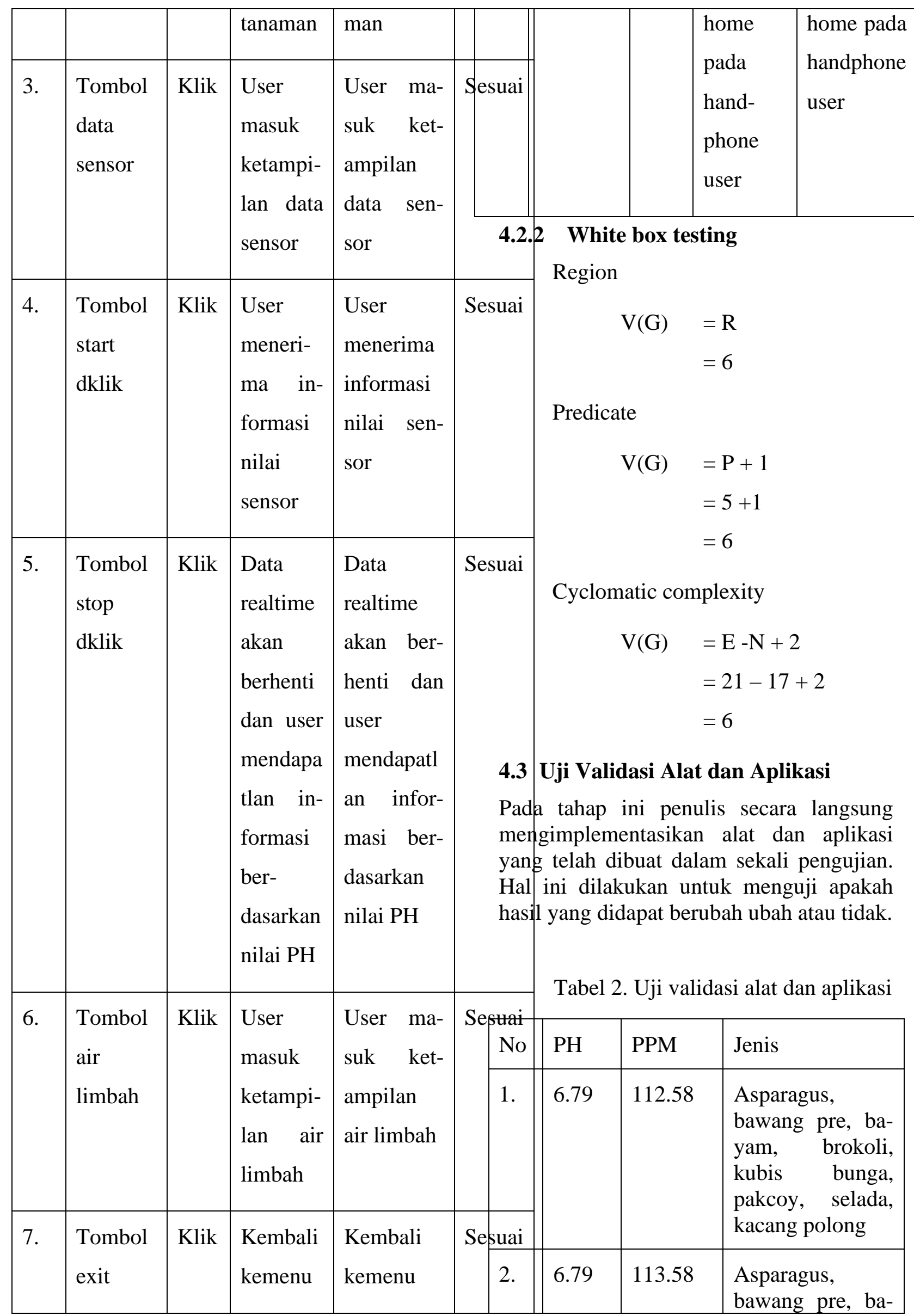




\begin{tabular}{|l|l|l|l|}
\hline & & & $\begin{array}{l}\text { yam, brokoli, } \\
\text { kubis bunga, } \\
\text { pakcoy, selada, } \\
\text { kacang polong }\end{array}$ \\
\hline 3. & 6.79 & 113.58 & $\begin{array}{l}\text { Asparagus, } \\
\text { bawang pre, ba- } \\
\text { yam, brokoli, } \\
\text { kubis bunga, } \\
\text { pakcoy, selada, } \\
\text { kacang polong }\end{array}$ \\
\hline 4. & 6.79 & 112.58 & $\begin{array}{l}\text { Asparagus, } \\
\text { bawang pre, ba- } \\
\text { yam, brokoli, } \\
\text { kubis bunga, } \\
\text { pakcoy, selada, } \\
\text { kacang polong }\end{array}$ \\
\hline
\end{tabular}

Dari hasil diatas nilai yang didapat pada masing masing sensor mengalami perubahan angka yang sedikit, dan untuk hasil rekomendasi tanaman yang diperoleh tetap sama. Namun, jika dilakukan pengujian yang berulang maka nilai yang diperoleh akan berbeda dengan nilai yang sebelumnya.

\section{Kesimpulan}

\subsection{Kesimpulan}

Dari hasil dan pembahasan yang penulis paparkan bahwa penelitian yang penulis lakukan dapat disimpulkan sebagai berikut:

1. Alat untuk mengukur tingkat $\mathrm{PH}$ dan zat padat terlarut dapat menggunakan alat sensor $\mathrm{PH}$ meter dan sensor TDS meter

2. Sensor PH meter dan sensor TDS meter yang digunakan pada penelitian ini mampu mengukur tingkat $\mathrm{PH}$,zat padat terlarut serta merekomendasikan tanaman hidroponik yang sesuai.

3. Dengan adanya aplikasi daur limbah masyarakat dapat mengetahui pemanfaatan kembali air limbah IPAL untuk tanaman hidroponik sesuai dengan nilai ph pada air yang dideteksi

4. Alat yang telah dibuat dapat mendeteksi tingkah ph dan zat padat terlarut pada air limbah IPAL.

5. Kemudahan dalam penggunaan aplikasi yang telah dibuat

\subsection{Saran}

Adapun saran yang dapat penulis berikan pada penelitian ini yaitu sebagai berikut:

1. Belum adanya perhitungan yang dapat menentukan nilai PPM yang sesuai dengan data tanaman hidroponik

2. Pada bagian data tanaman, diharapkan dapat memberikan jenis tanaman hidroponik yang lainnya.

3. Untuk penelitian selanjutnya, diharapkan pengembangan yang lebih baik sesuai dengan perubahan dan kebutuhan pada IPAL.

\section{Daftar Pustaka}

Ayu Kartika Puspa, A. C. (2020). Analisis kebutuhan Sistem informasi Terintegrasi Untuk Agribisnis Tanaman Pangan. Jurnal Management Sistem Informasi dam Teknologi.

Dr. Suryono, S. M. (2018). Teknologi Sensor (Konsep Fisis dan Teknik Akuisisi Data Berbasis Mikrokontroler $32 \quad$ Bit ATSAM3X8E (ARDUINO DUE) ). Semarang.

Erlangga Erlangga, H. S. (2020). Sistem Rekomendasi Beauty Shop Berbasis Collaborative Filtering. Jurnal Manajemen Sistem Informasi dan Teknologi, 47-52.

Fenty Ariani, E. T. (2018). Aplikasi berbasi web metode servqual untuk mengukur kepuasan mahasiswa terhadap layanan laboratorium 
komputer. Jurnal management sistem informasi dan teknologi.

Fenty Ariani, S. S. (2017). Aplikasi kepma untuk mengukur kepuasan mahasiswa menggunakan metode servqual berbasis android. Jurnal management sistem informasi dan teknologi.

Masduki, A. (2017). HIDROPONIK SEBAGAI SARANA PEMANFAATAN LAHAN.

Jurnal Pemberdayaan, Vol.1, No. 2, Oktober 2017, hal. 185-192, 185-192.

Prof.Dr Suryana, M. (2010). METODOLOGI PENELITIAN model prakatis penelitian Kuantitatif dan Kualitatif. 